\title{
Geopolymer Concrete by Using Fly Ash in Construction
}

\author{
Prof.M.A.Bhosale, Prof.N.N.Shinde \\ *(Energy, shivaji University,India) \\ ** (Department of Energy Technology, Shivaji University, Kolhapur
}

\begin{abstract}
: he alkali activation of waste materials is a chemical process that allows the user to transform glassy structures into very compact well-cemented composites. Nowadays, the knowledge concerning the mechanisms controlling the alkali activation process is considerably advanced; however, there are still many things to investigate. In the present paper, the mechanism of activation of a fly ash (no other solid material was used) with highly alkaline solutions is described. These solutions, made with $\mathrm{NaOH}$, Na2Sio3.This paper, report on the study of the processing of geopolymer using fly ash and alkaline activator with geopolymerization process. The factors that influence the early age compressive strength such as molarities of sodium hydroxide (NaOH) have been studied. Sodium hydroxide and sodium silicate solution were used as an alkaline activator. These studies comprises the comparison of the ratios of $\mathrm{Na} 2 \mathrm{SiO} \& \mathrm{NaOH}$ at the values $0.39 \& 2.51$.The geopolymer paste samples were cured at $60^{\circ} \mathrm{C}$ for 1 day and keep in room temperature until the testing days. The compressive strength was done at 7 and 28 days. The result showed that the geopolymer paste with $\mathrm{NaOH}$ concentration, compressive strength increase with molarities increases.
\end{abstract}

Keywords: Geopolymer, Alkali, Fly Ash, Class F, compressive Strength

\section{Introduction}

The most commonly used structural material for all types of construction is concrete to enhance the strength properties and serviceability requirements by using supplementary materials in concrete. Such supplementary materials are blast furnace slag, fly ash, silica fume, steel fibers, glass fibers, rice husk, crushed stone dust etc.

Every 1 ton of concrete leads to $\mathrm{CO}_{2}$ emissions which vary between 0.05 to 0.13 tons. About $95 \%$ of all $\mathrm{CO}_{2}$ emissions from a cubic yard of concrete are from cement manufacturing. It is important to reduce $\mathrm{CO}_{2}$ emissions through the greater use of substitute to ordinary Portland cement (OPC) such as fly ash, clay and others geo-based material. This project should be study on the processing of geopolymer using fly ash and alkaline activator with geopolymerization process. The factors that influence the early age compressive strength such as molarities of sodium hydroxide $(\mathrm{NaOH})$ need to be studied. Sodium hydroxide and sodium silicate solution were used as an alkaline activator. These studies comprise the comparison of the ratios of $\mathrm{Na}_{2} \mathrm{SiO}_{3} \& \mathrm{NaOH}$ at the values $0.39 \& 2.51$.

As far as India is concerned, the first ever study on use of fly ash in concrete was carried out in 1955 by CBRI, Roorkee(1), in the form of a review of American and Australian research work on Fly ash. Later, Fly ash was used in small proportions in mass concreting for dams and other hydraulic.

Ali Allah Verdi \&Frantisek Skvara[2000]2, investigated the response of harden paste of a geopolymer cement to acid attack \& compared to that of ordinary Portland cement. These cement was produced by activating a mixture of fly ash \& blast furnace slag using a proportioned solution of $\mathrm{NaOH} \& \mathrm{Na} 2 \mathrm{SiO} 3$. A.Buchwald, M.Hohmann \& Ch.Kaps[2000]3, investigation focuses the influence of the clay composition on the geopolymer performance. Clays with different kind \& amount of the clay mineral as well as side mineral were investigating.

The famous report on sustainable cement industry published by Batelle Institute: titled Climate Change, is available on the Internet at the following address: This report confirms the studies carried out by Prof. Joseph Davidovits since [1990]4, on CO2 emissions during Portland cement manufacture (in the LIBRARY the paper on Global Warming). Batelle's report recommends the development of geopolymer cement. John Zachar \& Tarun R. Naik[1990]5, use fly ash \& foundry sand \& slag as a replacement for cement and fine coarse aggregates in concrete. Davidovits [1988]6 proposed that an alkaline liquid could be used to react with the silicon $(\mathrm{Si})$ and the aluminum $(\mathrm{Al})$ in a source material of geological origin or in by-product materials such as fly ash and rice husk ash to produce binders. Because the chemical reaction that takes place in this case is a polymerization process, he coined the term Geopolymer to represent these binders. Geopolymer concrete is concrete which does not utilize any Portland cement in its production. Geopolymer concrete is being studied extensively and shows promise as a substitute to Portland cement concrete. Research is shifting from the chemistry domain to engineering applications and commercial production of geopolymer concrete.

There are two main constituents of geopolymers, namely the source materials and the alkaline liquids. The source materials for geopolymers based on alumina-silicate should be rich in silicon ( $\mathrm{Si}$ ) and aluminum 
(Al). These could be natural minerals such as kaolinite, clays, etc. Alternatively, by-product materials such as fly ash, silica fume, slag, rice-husk ash, red mud, etc could be used as source materials. The choice of the source materials for making geopolymers depends on factors such as availability, cost, type of application, and specific demand of the end users. The alkaline liquids are from soluble alkali metals that are usually sodium or potassium based. The most common alkaline liquid used in geopolymerisation is a combination of sodium hydroxide $(\mathrm{NaOH})$ or potassium hydroxide $(\mathrm{KOH})$ and sodium silicate or potassium silicate. This paper is devoted to heat-cured low-calcium fly ash-based geopolymer concrete. Low-calcium (ASTM Class F) fly ash is preferred as a source material than high-calcium (ASTM Class C) fly ash. The presence of calcium in high amounts may interfere with the polymerization process and alter the microstructure [Gourley and Johnson, 2005].

\section{Methodology And Experimental Program}

a) Objectives of the Investigation:

The objective of the present investigation is, to study the performance characteristics of the source materials

1) Study \& evaluation of chemical composition \& effects of $\mathrm{NaOH} \&$ sodium silicate on fly ash.

2) Study of polymerization process in Fly ash, $\mathrm{NaOH} \&$ sodium silicate of the composition that is geopolymer.

3) Testing of geopolymer by using universal testing machine.

4) Analysis of geopolymer testing \& comparison.

b) Materials Used:

Low calcium class $\mathrm{F}$ type fly ash

Sodium hydroxide (98\% purity in pure form)

Sodium silicate solutions ( $8 \mathrm{M}, 10 \mathrm{M}, 12 \mathrm{M}$ and $14 \mathrm{M})$

Coarse Aggregate ( $7 \mathrm{~mm}, 14 \mathrm{~mm} \& 20 \mathrm{~mm})$

Fine aggregate (fineness modulus $2.6-2.8$ )

Distilled Water.

2.2 chemical composition of Fly ash as supplied by RTPS,

\begin{tabular}{|l|c|}
\hline \multicolumn{1}{|c|}{ Characteristics } & fly ash(\%wt) \\
\hline Silica & $55-65$ \\
\hline iron oxide & $5-7$ \\
\hline aluminum oxide & $22-25$ \\
\hline calcium oxide & $5-7$ \\
\hline magnesium oxide & $<1$ \\
\hline titanium oxide & $<1$ \\
\hline Phosphorous & $<1$ \\
\hline Sulphates & 0.1 \\
\hline alkali oxide & $<1$ \\
\hline
\end{tabular}

2.1Physical Properties of low calcium class F Fly Ash

\begin{tabular}{|l|c|c|}
\hline $\begin{array}{l}\text { Physical } \\
\text { properties }\end{array}$ & $\begin{array}{l}\text { Properties of fly } \\
\text { ash used }\end{array}$ & $\begin{array}{l}\text { Properties of fly } \\
\text { ash according to } \\
\text { IS 1320-1981 }\end{array}$ \\
\hline Specific gravity & 2.51 & - \\
\hline $\begin{array}{l}\text { Initial setting } \\
\text { time }\end{array}$ & 120 minutes & - \\
\hline Final setting time & 280 minutes & - \\
\hline $\begin{array}{l}\text { Fineness specific } \\
\text { surface in } \text { m }^{2} / \mathrm{kg} \\
\text { min }\end{array}$ & 320 & 340 \\
\hline $\begin{array}{l}\text { Lime reactivity } \\
\text { Avg compressive } \\
\text { strength }\end{array}$ & 4.00 & 6.200 \\
\hline
\end{tabular}


1) In the research work, low calcium, class F dry fly ash obtained from Raichur is used as base material to make the geopolymers.

2) Sodium silicate $\left(\mathrm{Na}_{2} \mathrm{SiO}_{3}\right)$ mixed with sodium hydroxide $(\mathrm{NaOH})$ as an alkaline activator has been used in this study, $\mathrm{NaOH}$ in pellet form with $97 \%$ purity \& $\mathrm{Na} 2 \mathrm{SiO} 3$ consist of $\mathrm{Na} 2 \mathrm{O}=9.4 \%, \mathrm{SiO} 2=30.1 \%$ \& $\mathrm{H} 2 \mathrm{O}=60.5 \%$, with weight ratio $\mathrm{SiO} 2 / \mathrm{Na} 2 \mathrm{O}=3.20-3.30$ )

3) By varying the ratio of $\mathrm{Na} 2 \mathrm{SiO} 3 \& \mathrm{NaOH}$ i.e. 0.39 . \& 2.51

4) Oven dry curing temperature i.e., $60^{\circ}$ for time in 24 hours is kept constant.

2.3.Details of Mixes for $\mathrm{Na}_{2} \mathrm{SIO}_{3} / \mathrm{NaOH}=2.51$

\begin{tabular}{|c|c|}
\hline Materials & Mass $\left(\mathrm{Kg} / \mathrm{m}^{3}\right)$ \\
\hline Coarse aggregates & 277 \\
\hline $20 \mathrm{~mm}$ & 370 \\
\hline $14 \mathrm{~mm}$ & 647 \\
\hline $07 \mathrm{~mm}$ & 554 \\
\hline Fine sand & 408 \\
\hline $\begin{array}{c}\text { Fly ash } \\
\text { (low calcium ASTM } \\
\text { class F) }\end{array}$ & 103 \\
\hline Sodium silicate solution & 41 \\
\hline Sodium Hydroxide & \\
\hline
\end{tabular}

2.4. Details of Mixes for $\mathrm{Na}_{2} \mathrm{SIO}_{3} / \mathrm{NaOH}=\mathbf{0 . 3 9}$

\begin{tabular}{|c|c|}
\hline Materials & Mass $\left(\mathrm{Kg} / \mathrm{m}^{3}\right)$ \\
\hline Coarse aggregates & 277 \\
\hline $20 \mathrm{~mm}$ & 370 \\
\hline $14 \mathrm{~mm}$ & 647 \\
\hline $07 \mathrm{~mm}$ & 554 \\
\hline Fine sand & 408 \\
\hline $\begin{array}{c}\text { Fly ash } \\
\text { (low calcium ASTM } \\
\text { class F) }\end{array}$ & 41 \\
\hline $\begin{array}{c}\text { Sodium silicate } \\
\text { solution }\end{array}$ & $103(8 \mathrm{M})$ \\
\hline Sodium Hydroxide & \\
\hline
\end{tabular}

$150 \mathrm{~mm}$ cube specimens and $100 \mathrm{~mm} \times 200 \mathrm{~mm}$ cylinder specimens were used for obtaining the compressive strength respectively of gpc as per IS specification.

III. Compressive Strength Test (IS: 516 -1959)

The compressive strength of concrete is one of the most important and useful properties of concrete. In most structural application concrete is implied primarily to resist compressive stress. In this experimental investigation, only geopolymer concrete cubes are used for testing compressive strength. The load at which the control specimen ultimately fail is noted, compressive strength is calculated by dividing load by area of specimen .The figure 5.12 shows the apparatus for compressive strength testing.

$\mathrm{fc}=\mathrm{P} / \mathrm{a}$

Where $\mathrm{fc}=$ cube compressive strength in

$\mathrm{p} \quad=\quad$ cube compressive load causing failure in $\mathrm{n}$

a $=$ cross sectional area of cube in $\mathrm{mm} 2$

The compressive strength for mix designations $8 \mathrm{~m}$ to $14 \mathrm{~m}$ are shown in tables at 7 days and at 28 days. it is observed that as the molarity and $\mathrm{Na}_{2} \mathrm{SiO}_{3} / \mathrm{NaOH}$ ratio is increased the compressive strength increases. Result for compressive strength will be for 7 days $\& 28$ days for oven drying $\&$ ambient temperature. 
Compressive Strength Test Results at 7 Days

For Cube $150 \mathrm{~mm} X 150 \mathrm{~mm} X 150 \mathrm{~mm}$

\begin{tabular}{|c|c|c|c|}
\hline \multicolumn{4}{|c|}{ Table3.1 compressive strength test results at 7 days } \\
\hline & specimen & $\begin{array}{c}\text { compressive } \\
\text { strength } \\
\mathrm{N} / \mathrm{mm}^{2}\end{array}$ & $\begin{array}{l}\text { avg.compressive } \\
\text { strength } \mathrm{N} / \mathrm{mm}^{2}\end{array}$ \\
\hline \multirow{3}{*}{$8 \mathrm{~m}$} & sample 1 & 30.3 & \multirow{3}{*}{30.33} \\
\hline & sample 2 & 33.0 & \\
\hline & sample 3 & 28.0 & \\
\hline \multirow{3}{*}{$10 \mathrm{~m}$} & sample 1 & 34.0 & \multirow{3}{*}{36.8} \\
\hline & sample 2 & 37.0 & \\
\hline & sample 3 & 39.44 & \\
\hline \multirow{3}{*}{$12 \mathrm{~m}$} & sample 1 & 39.0 & \multirow{3}{*}{41.06} \\
\hline & sample 2 & 43.2 & \\
\hline & sample 3 & 44.0 & \\
\hline \multirow{3}{*}{$14 \mathrm{~m}$} & sample 1 & 44.0 & \multirow{3}{*}{42.83} \\
\hline & sample 2 & 46.0 & \\
\hline & sample 3 & 38.5 & \\
\hline
\end{tabular}

$\mathrm{Na}_{2} \mathrm{SiO}_{3}$

\begin{tabular}{|c|c|c|c|c|}
\hline \multirow[t]{15}{*}{$\mathrm{NaOH}$} & \multicolumn{3}{|c|}{$\begin{array}{c}\text { Compressive strength test results at } 28 \text { days } \\
\text { For cube } 150 \mathrm{~mm} \times 150 \mathrm{~mm} \times 150 \mathrm{~mm} \\
\end{array}$} & $\begin{array}{l}\text { ts at } 28 \text { days } \\
150 \mathrm{~mm}\end{array}$ \\
\hline & \multicolumn{4}{|c|}{ Table.3.2 compressive strength test results at 28 days } \\
\hline & & specimen & $\begin{array}{c}\text { compressive } \\
\text { strength } \\
\mathrm{N} / \mathbf{m m}^{2} \\
\end{array}$ & $\begin{array}{l}\text { avg.compressive } \\
\text { strength } \mathrm{N} / \mathrm{mm}^{2}\end{array}$ \\
\hline & \multirow{3}{*}{$8 \mathrm{~m}$} & sample 1 & 32 & \multirow{3}{*}{32.83} \\
\hline & & sample 2 & 36.5 & \\
\hline & & sample 3 & 30 & \\
\hline & \multirow{3}{*}{$10 \mathrm{~m}$} & sample 1 & 37 & \multirow{3}{*}{37.5} \\
\hline & & sample 2 & 37.5 & \\
\hline & & sample 3 & 38.0 & \\
\hline & \multirow{3}{*}{$12 \mathrm{~m}$} & sample 1 & 45 & \multirow{3}{*}{43.5} \\
\hline & & sample 2 & 41.5 & \\
\hline & & sample 3 & 44 & \\
\hline & \multirow{3}{*}{$14 \mathrm{~m}$} & sample 1 & 47 & \multirow{3}{*}{47.43} \\
\hline & & sample 2 & 50.5 & \\
\hline & & sample 3 & 44.8 & \\
\hline \multicolumn{5}{|c|}{$\mathrm{Na}_{2} \mathrm{SiO}_{3}$} \\
\hline
\end{tabular}

fig.casting of specimen

fig. setup for compressive strength
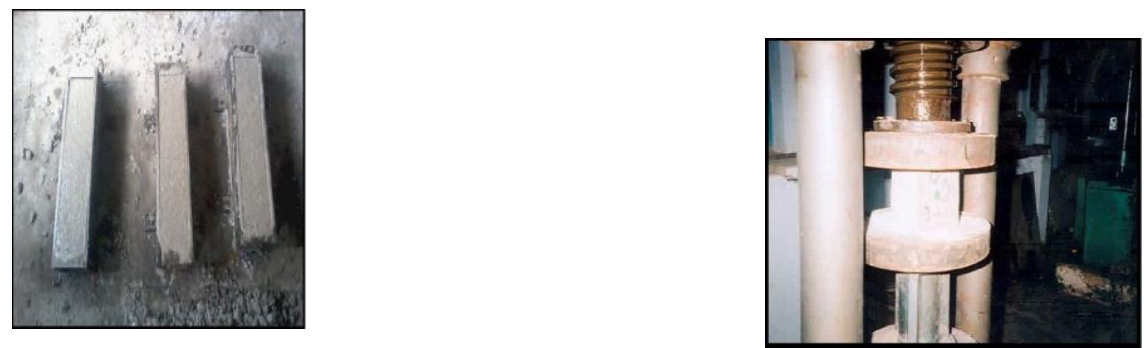
Compressive Strength Test Results at 7 Days

For Cube 150mm X 150mm X 150mm

\begin{tabular}{|c|c|c|c|}
\hline \multicolumn{4}{|c|}{ Table 3.3 : compressive strength test results at 7 days } \\
\hline & specimen & $\begin{array}{l}\text { compressive } \\
\text { strength } \\
\mathbf{N} / \mathbf{m m}^{2}\end{array}$ & $\begin{array}{l}\text { avg.compressive } \\
\text { strength } \mathrm{N} / \mathrm{mm}^{2}\end{array}$ \\
\hline \multirow{3}{*}{$8 \mathrm{~m}$} & sample 1 & 13.0 & \multirow{3}{*}{15.83} \\
\hline & sample 2 & 18.0 & \\
\hline & sample 3 & 16.5 & \\
\hline \multirow{3}{*}{$10 \mathrm{~m}$} & sample 1 & 14.9 & \multirow{3}{*}{17.0} \\
\hline & sample 2 & 17.0 & \\
\hline & sample 3 & 17.1 & \\
\hline \multirow{3}{*}{$12 \mathrm{~m}$} & sample 1 & 19.11 & \multirow{3}{*}{17.16} \\
\hline & sample 2 & 15.19 & \\
\hline & sample 3 & 17.2 & \\
\hline \multirow{3}{*}{$14 \mathrm{~m}$} & sample 1 & 19.3 & \multirow{3}{*}{17.3} \\
\hline & sample 2 & 15.31 & \\
\hline & sample 3 & 17.29 & \\
\hline
\end{tabular}

$\mathrm{Na}_{2} \mathrm{SiO}_{3}$

\begin{tabular}{|c|c|c|c|}
\hline \multicolumn{4}{|c|}{$\begin{array}{c}\text { Compressive Strength Test Results at } 28 \text { Days } \\
\text { For Cube 150mm X 150mm X 150mm }\end{array}$} \\
\hline \multicolumn{4}{|c|}{ Table 3.4 : compressive strength test results at 28 days } \\
\hline & specimen & $\begin{array}{l}\text { compressive } \\
\text { strength } \\
\mathbf{N} / \mathbf{m m}^{2}\end{array}$ & $\begin{array}{l}\text { avg.compressive } \\
\text { strength } \mathrm{N} / \mathrm{mm}^{2}\end{array}$ \\
\hline \multirow{3}{*}{$8 \mathrm{~m}$} & sample 1 & 14 & \multirow{3}{*}{16.16} \\
\hline & sample 2 & 17.2 & \\
\hline & sample 3 & 17.3 & \\
\hline \multirow[b]{2}{*}{$10 \mathrm{~m}$} & sample 1 & 18 & \multirow{3}{*}{19.13} \\
\hline & sample 2 & 19.2 & \\
\hline & sample 3 & 20.2 & \\
\hline & sample 1 & 23.3 & \multirow{3}{*}{20.56} \\
\hline $12 \mathrm{~m}$ & sample 2 & 17.39 & \\
\hline & sample 3 & 21 & \\
\hline & sample 1 & 24.3 & \multirow{3}{*}{21.46} \\
\hline $14 \mathrm{~m}$ & sample 2 & 18.5 & \\
\hline & sample 3 & 21.6 & \\
\hline
\end{tabular}

$\mathrm{Na}_{2} \mathrm{SiO}_{3}$

$\mathrm{NaOH}$

at $=$ ambient temperature

\section{Conclusion}

The construction industry is in demand of ecofriendly \& greener materials which are durable. As compared to the existing concrete materials, fly ash is advantageous but its uses as tested against strength \& durability needs to be confirmed.The present project work emphasis on the research \& development activity in construction materials using fly ash with geopolymers.

The project work revels with preparation of test samples of fly ash with geopolymers of different composition in the ratio of $0.39 \& 2.51$.The samples are prepared with the different molarities such as 8,10,12,14.

Tests for compressive strength, split tensile strength, flexural strength, rebound hammer test, acid resistant test are carried out on samples as above for ambient temperature(A.T) \& oven drying (O.D) for $7 \& 28$ days, as per prevailing standards for respective properties. The details of the results are summarized as under. 


\section{Compressive strength test:}

1. For ratio $\mathrm{Na}_{2} \mathrm{SiO}_{3} / \mathrm{NaOH}=2.51$, As higher concentration in terms of molar of solutions, results in higher compressive strength of fly ash based geopolymer concrete

2. For ratio $\mathrm{Na}_{2} \mathrm{SiO}_{3} / \mathrm{NaOH}=0.39$, It is observed that, when quantity of sodium silicate \& sodium hydroxide is reversed by mass, it is observed that compressive strength increases as increase in molarity.

For both cases that is $1 \& 2$ compressive strength is more for oven drying as compare to specimen left in ambient temperature.

\section{References}

[1]. Ali Allah Verdi \&Frantisek Skvara 2000.as in (2) - "response of harden paste of a geopolymer cement to acid attack.."

[2]. A.Buchwald, M.Hohmann\&Ch.Kaps 2002 as in (3)- The influence of the clay composition on the geopolymer performance.

[3]. Prof. Joseph Davidovits since 1990 as in (4) on $\mathrm{CO}_{2}$ emissions during Portland cement manufacture (in the LIBRARY the paper on Global Warming).

[4]. John Zachar \& Tarun R. Naik as in (5)- "use fly ash \& foundry sand \& slag as a replacement for cement and fine coarse aggregates in concrete

[5]. Davis, R,E., R. W. Carlson, J. W. Kelly, and A. G. Davis, as in (6) 'Properties of cements and concretes containing fly ash', Proceedings, American Concrete Institute 33:577-612.

[6]. [06] Mehta, P.K., and R.W.Burrows, 2001, as in (7) "Building Durable Structures in the 21st Century." Concrete International 23(3), pp. 57-63."

[7]. Mehta, P.K., 1999, 'Concrete Technology for sustainable development', Concrete International 21 (11), pp. 47-52.

[8]. Report No. T(S) 006, January, 2005, 'Use of higher volume fly ash in concrete for building sector', CBRI, Roorkee.

[9]. Yadava K.P., Tyagi B.S., Pandey K.K. and Singh V. N., January, 1987, 'Fly ash for the treatment of Cd(11) rich effluents', Environmental technology Journal, Volume 8, Issue 1-12, pp.225-234.

[10]. Davis, R,E., R. W. Carlson, J. W. Kelly, and A. G. Davis, 'Properties of cements and concretes containing fly ash', Proceedings, American Concrete Institute 33:577-612.

[11]. Verma, S.,1997, 'Performance Evaluation of High strength Fly ash concrete paving mixes', M.E. Dissertation, Department of Civil Engineering, University of Roorkee, Roorkee, India.

[12]. Prasad, P.V. S. and Jha, K., 'High Performance Concrete', Project work for Course No. 624- Sr. Professional Course (Bridges and General),IRICEN, Pune.

[13]. Aitcin, P.C, Mehta, P.K., 1990, "Principles Underlying the Production of High- Performance Concrete." Cement, Concrete and Aggregates ournal 12(2), pp. 70-78.

[14]. Mehta,P.K., and R.W.Burrows, 2001, "Building Durable Structures in the 21st Century." Concrete International 23(3), pp. 57-63.

[15]. Mehta, P.K. and Gjorv O. E., 1982, 'Properties of Portland Cement Concrete containing Fly ash and Condensed Silica Fume', Cement and concrete Research Journal, Vol. 12, No. 5, pp.587-595.

[16]. Adams, T. H., 1988, "Marketing of fly ash concrete", MSU seminar: Fly ash applications to concrete (January), 1.10, 5.10, East Lansing: Michigan State University.

[17]. Naik, T. R. and Ramme B.W. 1989, 'High Strength Concrete containing large quantity of fly ash', ACI Material Journal, Vol.86, No.2, pp.111-116

[18]. Raju, N. K., Ipe, T. V. and Srinath, N., 1994,'mix Proportioning and strength characteristics of portland cement and pulverized fly ash concrete', ICI Bulletin No.49, pp.27-32.

[19]. American Coal Ash Association, 1995, 'Fly Ash Facts for Highway Engineers', Federal Highway Administration, Report No. FHWA-SA- 94-081, Washington, DC, December

[20]. Ho.D.W.S and Lewis R.K. 1983. "Carbonation of concrete incorporating fly ash or a chemical admixture".

[21]. Malhotra V.M. and Mehata P.K. 2002. "High - performance, high - volume fly ash concrete". 